\title{
Cultural Identity as the Basis of Modern Cultural Typologies
}

\author{
Dorzhi L. Khilkhanova and Erzhen V. Khilkhanovab,c* \\ ${ }^{a}$ Moscow City University \\ Moscow, Russian Federation \\ ${ }^{b}$ Institute of Linguistics of the RAS \\ Moscow, Russian Federation \\ ${ }^{c}$ Buryat State University \\ Ulan-Ude, Russian Federation
}

Received 29.08.2021, received in revised form 02.09.2021, accepted 14.09.2021

\begin{abstract}
The purpose of this article is to show the significance of markers of cultural identity for modern ethnometric typologies. In the modern period of modernization various cultural typologies are becoming popular. They are compiled based on multicomponent factors. The authors briefly describe these classifications as traditional markers of identity, such as religion, and new factors of psychology and mentality. The modern concept that explains the hybridization of modern cultural forms is transculturation. The transcultural manifestations include a certain decline of the role of the native language and the transformation of the traditional production niche of ethnic groups in Siberia. The traditional perception of identity consists mainly of cultural, religious and linguistic characteristics. At the same time, the typology of L. Harrison shows the positive correlation between the cultural and industrial-economic components. This historical fact was noted by the famous anthropologist Frederik Barth, who focused on the production component of the ethnic border as opposed to the cultural one. The existing significant differences in the professional structure among Russians and Buryats in the twentieth century prove the fact that ethnic borders, despite the globalization / modernization processes, can still be associated with a certain production niche. The authors come to the conclusion that cultural markers still retain their significance, but can be implemented in hybrid forms of transculturation. These processes are reflected in these cultural typologies in the forms of multicomponent factors.
\end{abstract}

Keywords: cultural typologies, ethnometric typologies, cultural identity, markers of cultural identity, transculturation, Siberia, Buryats.

Research area: philosophy of culture.

Citation: Khilkhanov, D.L., Khilkhanova, E. V. (2021). Cultural identity as the basis of modern cultural typologies. J. Sib. Fed. Univ. Humanit. soc. sci., 14(10), 1468-1473. DOI: 10.17516/1997-1370-0831

\footnotetext{
(C) Siberian Federal University. All rights reserved

* Corresponding author E-mail address: dorjikh@mail.ru, erzhen133@mail.ru ORCID: 0000-0002-9382-7757 (Khilkhanov); 0000-0001-9369-343X (Khilkhanova) 


\title{
Культурная идентичность
}

\section{как основа современных этнометрических типологий}

\author{
Д.Л. Хилханова , Э.В. Хилхановаб, в \\ амосковский городской педагогический университет \\ Российская Федерачия, Москва \\ ${ }^{6}$ Институт языкознания РАН \\ Российская Федерачия, Москва \\ ${ }^{6}$ Бурятский государственный университет \\ Российская Федерачия, Улан-Удэ
}

\begin{abstract}
Аннотация. Цель данной статьи - показать значение маркеров культурной идентичности для современных этнометрических типологий. В современный период модернизации популярными становятся различные культурные типологии. Как правило, они составляются на основе многокомпонентных факторов. В своей статье мы показываем, что в основе этих классификаций лежат как традиционные маркеры идентичности, например религия, так и новые комплексные факторы, относящиеся к психологии и мировоззрению. Современной концепцией, объясняющей неизбежную гибридизацию культурных форм, является транскультурация. К транскультурным проявлениям мы относим снижение роли родного языка и трансформацию традиционной производственной ниши этносов в условиях Сибири. Традиционное восприятие идентичности складывается преимущественно из культурных, религиозных и языковых признаков. В то же время рассмотренные нами типологии (например, типология Л. Харрисона) обосновывают взаимосвязь культурной и производственноэкономической составляющей. Данный факт отмечал норвежский антрополог Фредерик Барт, который акцентировал внимание на производственной составляющей этнической границы в противовес культурным. Существующие значимые различия в выборе профессий у русских и бурят в XX веке доказывают тот факт, что этнические границы, несмотря на глобализационные/модернизационные процессы, могут быть связаны с определенной производственной нишей. В качестве заключения мы отмечаем, что культурные маркеры по-прежнему сохраняют свое значение, но могут реализовываться уже в гибридных формах транскультурации. Данные процессы отражены в рассмотренных типологиях в виде многокомпонентных факторов.
\end{abstract}

Ключевые слова: культурные типологии, этнометрические типологии, культурная идентичность, маркеры культурной идентичности, транскультурация, Сибирь, буряты.

Научная специальность: 09.00.013 - философская антропология, философия культуры.

\section{Introduction}

Currently, processes of socio-economic, political and cultural modernization lead to the growth of intercultural interaction. These processes are described through the construction of various ethnometric typologies. The results of these classifications are used in scientific humanitarian research, in international business communication and management, in the analysis of practical aspects of intercultural communica- tion, in various political, marketing, commercial projects etc. These classifications still remain on the markers of cultural identity. In our work we analyze the classification factors of modern cultural typologies and their correlation to the forms of traditional cultural identity.

\section{Theoretic framework}

The most well-known classification model today is the typology of cultural consequenc- 
es by Geert Hofstede (https://www.hofstedeinsights.com). Firstly, the author, based on the analysis of the results of IBM employees survey (40 countries, 116000 employees), in the 1970s, identified four main cultural factors for his classification, which he called: «Power Distance Index»,»Uncertainty avoidance», «Individualism/collectivism», «Masculinity» (Hofstede, 1980). In the 1980s, based on research in East and Southeast Asia conducted by the Canadian psychologist Michael Harris Bond, a fifth dimension was created - «Long term orientation» (Hofstede, Bond, 1988). At the beginning of the twenty-first century, the sixth factor «Indulgence» was added (Minkov, 2011).

Geert Hofstede placed the countries under study in the data space of six factors. His research, «Culture's Consequences: Comparing Values, Behaviors, Institutions and Organizations across Nations» (Hofstede, 2001), is the most cited book in the cross-cultural management area, so we do not describe this one. In fact, these six factors are based on certain cultural values of nations. These are the cultural characteristics, values, traditions and customs of a country that determine the factor meanings of each attribute for a particular country or national culture. In general, these ethnometric features are complex components of cultural identity and reflect the system of traditional values. In his works, Hofstede recognized the priority of traditional cultural values. «Social, national or gender cultures that are instilled from early childhood have much deeper roots in the human consciousness than the cultures of professional groups acquired with education, or than the various organizational cultures acquired during work» (Hofstede, 2011).

The following classification that we want to note is created within the framework of the World Values Survey. This study is the largest survey in the world since the 1980s, and its findings for 97 countries are considered representative. According to R. Inglehart, socioeconomic modernization usually leads to a significant transformation of cultural values and, in fact, to a change in cultural identity (Inglehart, 1997). As a result of the economic modernization of recent years, most of the countries participating in the World Values Survey un- der the leadership of R. Inglehart demonstrate a constant trend of countries moving towards the values of self-expression, which is clearly demonstrated by the map of cultural orientations (https://www.worldvaluessurvey.org/wvs. jsp). These authors considered such criteria as: traditional-secular-rational values and values of survival-self-expression (Inglehart, Welzel, 2005). The values of self-expression are based on the European democratic values of liberalism and individualism, the values of survival on the ideas of collectivism and authoritarianism. In this work, R. Inglehart defines traditional values in the context of religious identity. As you know, the main factor of ethnic identity is the native language, and the second most important is religion. Thus, this typologization is based on such a determinant factor of cultural identity as religion.

Finally, we want to consider the typology of Lawrence Harrison's cultural traditions. This author analyzes countries in the space of 25 parameters: Religion, Destiny, Time orientation, Wealth, Knowledge, Ethical code, The lesser virtues, Education, Work/achievement, Frugality, Entrepreneurship, Risk propensity, Competition, Innovation, Advancement, Rule of law/corruption, Radius of identification and trust, Family, Association (social capital), The individual/the group, Authority, Role of elites, Church-state relations, Gender relationships, Fertility (Harrison, 2006). These factors determine the cultural resource for the success of economic modernization in a particular country. At the same time, this classification in the most complete one described the factors of cultural identity. L. Harrison emphasizes the determining role of religious factors as a most significant component and as a formal system of relations between secular and religious values.

These typologies mainly demonstrate stability of certain cultural forms. Their authors consider national cultures in the aspect of quantitative factors (six dimensions) according to G. Hofstede, as a coordinate system of $\mathrm{R}$. Inglehart, one of the axes of which is the religious-secular factor. L. Harrison in his classification, to the greatest extent, analyzes the main markers of cultural identity in terms of their importance for economic development. 
G. Hofstede and L. Harrison noted the priority of cultural values, their crucial role for the economy and management, R. Inglehart considers his typology as an evidence of the processes of cultural values changes. At the same time, the map of cultural values demonstrates, in the dynamics of recent years, the high influence of traditional (religious) values in the countries. For example, Russia, according to this scale, fell from a relatively high position of secular values +1.3 in 1990 to +0.5 in 2020 in the direction of traditional (religious) values (https://www.worldvaluessurvey.org/wvs.jsp).

These classifications are the most wellknown ethnometric models. There are also other typologies, such as the GLOBE project by Robert House (About the Foundation - GLOBE Project) (House, Hanges, Javidan, Dorfman, Gupta, 2004), organization typology by Fons Trompenaars (Trompenaars, 2003), but they are relatively specific and professional oriented, therefore could not be representative in the paper.

\section{Discussion}

The processes of globalization in the modern world actualize the phenomenon of cultural identity, primarily in ethnic aspects. In general, the typologies of cultural dimensions reflect the factors of traditional cultural identity, emphasizing their relevance for the classification of countries.

According to the principles of diffusion, cultural differences decreased in cross-cultural process of globalization. State policy of a unified national identity accompanied this process of acculturation. At the same time, ethnic groups tend to strengthen their cultural identity. There is a confrontation between the trends of globalization and glocalization. As a result of the growth of cross-cultural and economic interaction, the phenomenon of transnationalism and the concept of transculturation arise, as opposed to the theories of acculturation and assimilation. There is no doubt that the social and cultural distances between ethnic groups tend to decrease, as shown by the data of seven mass surveys of the World Values Survey from 1981 to 2020 , but they can also be maintained through modifications to hybrid cultural forms according to the concept of transculturation.
These typologies, as well as the entire modern experience of intercultural interaction, demonstrate the stability of the phenomenon of cultural identity even in the context of global modernization. Cultural identity demonstrates its stability, firstly, because it is broader than just ethnic or linguistic one, and secondly, cultural identity can exist in non-verbal forms (Khilkhanova, Khilkhanov, 2020). The native language, first of all, is a marker of ethnic identity, and in the modern conditions of globalization, it can reduce its identification value (Khilkhanova, 2020). The decline in the role of the native language, the increase of religious values in the context of modernization can be explained by the processes of transculturation.

The problems of cultural identity transformation are considered by various philosophical concepts. In modern society, the concept of transculturation is gradually replacing the Eurocentric models of acculturation and multiculturalism, when explaining the phenomena and consequences of intercultural interaction. In most studies, this theory is perceived as the main principle of the functioning of modern cultural forms in the era of globalization (Tlostanova, 2011: 133). This concept logically explains the nature of cultural changes among ethnic groups in the context of socio-economic modernization.

The traditional perception of identity consists mainly of cultural, religious and linguistic characteristics. At the same time, the typologies justify the relationship between the cultural and industrial-economic components. Most researchers do not consider the industrial specialization of an ethnic group in the context of identification. In our opinion, cultural values were determined by the production niche of the ethnic group, and in the future, according to L. Harrison, they ensured the success or failure of modernization. The production niche of an ethnic group is the economic and cultural type that is traditional for an ethnic group and is determined by its natural, spatial, and cultural environment (Khilhanov, 2007: 14). Initially the relationship between cultural identity and the traditional way of managing was noted by anthropologist Frederik Barth. He focused on 
the production component of the ethnic border, rather than on the complex of cultural characteristics. As a result, the scientist determined the main role of industrial relations for the ethnic border, and in general for the phenomenon of cultural identity (Bart, 1969).

Specific production patterns have been formed in Siberia for centuries. Representatives of different ethnic groups (Russians, Buryats, Evenks) developed various labor skills that determined the norms, traditions and values of the social group within the framework of production specialization (farmers, ranchers, hunters).

Geographical and climatic factors in Siberia resulted in the widespread traditions of nomadic and semi-nomadic cattle breeding. These traditions corresponded to cultural complexes of ideas, images, traditions and rituals characteristic of nomadic life.

A particularly stable relationship between ethnicity and production patterns is observed among the small peoples of Siberia and the Russian North. In the twentieth century, radical changes in the daily life of fishermen and reindeer herders of the Russian North often destroyed their traditional way of life and gave rise to a whole complex of current social and cultural problems (Vahtin, 2020).

Foreign and domestic experience shows that the peoples who can preserve the traditional economy as a life-supporting factor also preserve the basic elements of traditional culture. Another question is that in the context of global modernization, the preservation of traditional forms of management is unlikely. Rather, professional transformation leads to occupations in the informal economy: poaching, illegal fishing, illegal gold mining, etc. (Klokov, 2020). These processes can be analyzed on the example of the Buryats, the largest ethnic group in Siberia.

The construction of the cultural border, the formation of the opposition "We-They» among the Buryats took place in the conditions of contacting mainly with the Russian population. In the course of historical development, the Buryats acquired multiple cultural identities: tribal, regional, ethnic, Mongolian, Buddhist, and Russian.
Historically, the main level of identification for the Buryats was connected with kinship ties. From an administrative point of view, the family resembles a Russian community. As you know, the community was the main administrative association for the peasants, and was supported by the state for fiscal purposes. Communal farming, the practical absence of private ownership of land, determined the priority of traditional collectivist cultural values among the Russian population. As it is known, the attempts of the Russian goverment to destroy the community and to create farms in the beginning of twentieth century, were not successful, partly because of the priority of the peasant collective values of survival. Before the revolution, the Buryat clan also owned the main allotments of land (mowing), which were regularly distributed among its members. The Buryat kinship ties was primarily a phenomenon of socio-economic and administrative nature, the features of which determined cultural traits and values, as well as the communal way of life determined the collective mentality of the Russian peasantry. Today, the ancestral affiliation of the Buryats corresponds to belonging to certain district communities. Such a transformation of ancestral identity can be attributed to the modern manifestations of transculturation.

In our opinion, when we look at the Buryats (as well as other Siberian peoples in the conditions of modernization) in the twentieth century, we can observe a change in the content in the production niche itself. At the same time, cultural identity largely determined the choice of a production niche. The data of The Russian census of 2002 showed that the main part of the Russian population in the Republic of Buryatia works in the manufacturing industry (137 people out of 1000), in trade (118), in public administration and defense (106), in education (103). Buryats are employed in education (203), trade (119), public administration and defense (117), health (116) and agriculture, hunting and forestry (102) (Khilhanov, 2007:221).

\section{Conclusion}

The existing significant differences in the professional choices among Russians and 
Buryats prove the fact that ethnic boundaries, despite the globalization / modernization processes, can still be associated with a certain production niche. The cultural identity of the Buryat and Russian populations still influences the structure of their employment. Thus, cultural identity is directly related to the economic component, which is directly reflected in the modern typology of L. Harrison. The modern classifications of G. Hofstede and $\mathrm{R}$. Inglehart are based on a multidimensional factor analysis of traditional features of cultural identity. The authors of this article note that when analyzing these classifications, it is necessary to know the fact that cultural markers still retain their value, but can be implemented already in hybrid forms of transculturation.

\section{References}

Bart, F. (ed.) (1969). Ethnic Groups and Boundaries. Boston: Little, Brown.

Harrison, L. (2006). The Central Liberal Truth. NY.; Oxford: Oxford University Press.

Hofstede, G. (1980). Culture's Consequences: International Differences in Work-Related Values. Beverly Hills CA: Sage.

Hofstede, G., Bond, M. H. (1988). The Confucius connection: from cultural roots to economic growth. In Organizational Dynamics, 16(4), 4-21.

Hofstede, G. (2001). Culture's Consequences: Comparing Values, Behaviors, Institutions and Organizations across Nations. $2^{\text {nd }}$ ed.Thousand Oaks CA: Sage.

Hofstede, G. (2011). Dimensionalizing Cultures: The Hofstede Model in Context. Online Readings in Psychology and Culture, Unit 2. URL: Available at: http://scholarworks.gvsu.edu/orpc/vol2/iss1/8. (accessed 19 February 2021)

House, R. J., Hanges, P. J., Javidan, M., Dorfman, P. W., Gupta, V. (Eds.), (2004). Culture, Leadership, and Organizations: The GLOBE Study of 62 Societies. Thousand Oaks CA: Sage.

Inglehart, R. (1997). Modernization and Postmodernization: Cultural, Economic and Political Change in 43 Societies. Princeton, NJ: Princeton University Press.

Inglehart, R., Welzel, C. (2005). Modernization, Cultural Change, and Democracy: The Human Development Sequence, New York: Cambridge ed.University Press

Khilkhanova, E.V., Khilkhanov, D.L. (2020). Etnokul'turnaya identichnost' migrantov iz vostochnyh regionov byvshego SSSR v svete teorii «stolknoveniya kul'tur» [Ethnocultural identity of migrants from the eastern regions of the former USSR in the light of the theory of «clash of cultures»], In Polilingvial'nost' i transkul'turnye praktiki. [In Polylinguiality and transcultural practices] Vol. 17. No. 1. 31-38. DOI 10.22363/2618-897X-2020-17-1-31-38

Khilkhanova, E.V. (2020) Mnogoyazychie postsovetskoj migracii: funkcional'nyj aspekt [Multilingualism of post-Soviet migration: a functional aspect], In Sociolingvistika. [In Sociolinguistic], 1 (1),. 63-78

Khilhanov, D. L. (2007) Etnicheskaya identichnost': rol' hozyajstvenno-ekonomicheskih i kul'turnoyazykovyh faktorov. Diss... d-ra sociol. nauk. [Ethnic identity: the role of prodaction-economic and cultural-linguistic factors. Diss... Doctor of Sociology]. lan-Ude. Buryat state university.

Klokov, K. B.(2020) Mezhdu gosudarstvom i rynkom: neformal'nye praktiki prirodopol'zovaniya v sibirskih selah [Between the state and the market: informal practices of nature management in Siberian villages], In Etnografiya [Ethnography], 1 (7), 142-165

Minkov, M. (2011). Cultural differences in a globalizing world. Bingley UK: Emerald.

Trompenaars, F. (2003) Did the pedestrian die? Capstone Publishing.

Tlostanova, M.V. (2011). Transkul'turaciya kak model' sociokul'turnoj dinamiki i problema mnozhestvennoj identifikacii [Transculturation as a model of socio-cultural dynamics and the problem of multiple identification] In Voprosy social'noj teorii. [In Questions of social theory], Volume 5, 126-149.

Vahtin, N.B. (2020) Antropologiya Severa. Kak izmenilas' zhizn' na Severe v XX veke. [Anthropology of the North. How life in the North changed in the twentieth century]. Available at: /arzamas.academy/ courses/76/4 (accessed 28 December 2020) 